ISSN No. 0974-035X

An Indexed, Refereed \& Peer Reviewed Journal of Higher Education

Towards Excellence

UGC-HUMAN RESOURCE DEVELOPMENT CENTRE,

GUJARAT UNIVERSITY, AHMEDABAD, INDIA

\title{
A STUDY OF EFFECTIVENESS OF INQUIRY TRAINING MODEL IN SOME UNITS OF BIOLOGY STANDARD XI
}

\section{Dr.Dhaval R.Patel}

\section{INTRODUCTION}

Teaching Biology through Inquiry requires that students ask questions and figure things out for themselves. It involves the attempt to answer questions and seek information. Inquiry can be conducted in a variety of ways: observing nature, predicting outcomes, manipulating variables, analyzing situations, and verifying assertions. It may involve discussing topics with others, reading, conducting field studies, surveys, and laboratory investigations, or all of these as one attempts to discover new knowledge and to figure things out.

The Inquiry Model developed by J.RichardSuchman in the United States in 1942.The Suchman Inquiry Training Model can be used with any subject. It is based on the premise that the intellectual strategies used by scientists to solve problems and inquire into the unknown can be taught to students. Using the natural curiosity of students, they can be trained and disciplined in the procedures of inquiry. The model was developed from analyzing the methods used in creative research personnel. The elements of their inquiry process were identified and these were built into an instructional model called Inquiry Training.

Inquiry Training is designed to bring students directly into the scientific process through exercises that compress the scientific process into small periods of time. The training has resulted in an increased understanding of science, more creative thinking, and skills for obtaining and analyzing information as students establish facts, build concepts, and then generate and test explanations or theories. The students are active learners involved in exploration, questioning, problem solving, inductive reasoning, invention, labeling, and discovery. 


\section{OBJECTIVES OF THE STUDY}

In the present study the objectives are as follows:

1) To study the effectiveness of Inquiry training model on academic achievement of students in Biology of standard XI.

2) To compare the achievement of students studying through Inquiry training model and traditional method for teaching Biology.

3) To compare the achievement of boys of the experimental group and Control group in Biology of standard XI.

4) To compare the achievement of girls of the experimental and controlled group in Biology of standard XI.

5) To compare the achievement of boys and girls of experimental group in Biology of standard XI.

\section{HYPOTHESIS OF THE STUDY}

The following hypotheses were generated for the study:

Ho1: There will be no significant difference between Mean scores of achievement of students studying through Inquiry training model and traditional method in Biology of Standard XI.

Ho2: There will be no significant difference between the mean scores of the achievement of boys of Experimental group and control group of standard XI in Biology.

Hoz: There will be no significant difference between the mean scores of the achievement of girls of Experimental group and control group of standard XI in Biology.

Ho4: There will be no significant difference between the mean scores of the achievement of boys and girls Experimental group of standard XI in Biology.

\section{POPULATION OF THE STUDY}

The English medium higher secondary school (Eleventh standard) students of Gujarat state studying in the academic year 2014-15 were the population of the study.

\section{DESIGN OF THE STUDY}


The researcher was interested in knowing the effectiveness of Inquiry Training Model in Biology subject and so took up this study.

Research design is a plan of action; it is used to structure the research, to show how the major parts of the research project. The sample or groups measures, treatments or programmes, and method of assignment work together to try to address the central research questions.

This Study adopted an experimental method and post-test were administered to equivalent group purposive sampling of XI standard of the Gyandeep higher Secondary School.

\section{TABLE - 1 \\ DESIGN OF THE STUDY}

\begin{tabular}{|c|c|c|}
\hline Phase & Control group & Experimental Group \\
\hline Experimental Interventions & $\begin{array}{l}\text { Lecture method } \\
\text { (Traditional Method) }\end{array}$ & Inquiry Training Model \\
\hline Post-Test & $\begin{array}{l}\text { Multiple Choice questions ( } 25 \\
\text { marks) }\end{array}$ & $\begin{array}{l}\text { Multiple Choice } \\
\text { questions ( } 25 \text { marks) }\end{array}$ \\
\hline Class & $\mathrm{XI}^{\mathrm{th}}$ & $\mathrm{XI}^{\mathrm{th}}$ \\
\hline $\begin{array}{l}\text { Total no. of Students } \\
\text { (N) }\end{array}$ & 30 & 30 \\
\hline
\end{tabular}

\section{RESEARCH METHODOLOGY}

In this study the researcher has adopted experimental method to carry out research work the researcher has selected 60 students' standards XI as a sample for the study. Considered their unit test marks to equalize the group and then purposively, dividing them into two groups i.e. controlled group and experimental group.

\section{CONTROL GROUP}


The group that does not receive any experimental treatment is called the controlled group. It is the group that is not exposed to some independent variable or is exposed to another independent variable for comparison purposes. Here this group is taught by lecture method.

\section{EXPERIMENTAL GROUP}

The group that is given the independent variable treatment (Inquiry training Model) or is exposed to some independent variable and called the experimental group. Here this group is taught by Inquiry Training method.

It provides the researcher an opportunity for the comparison required by the hypothesis of the experiment and enables researcher to make a meaningful interpretation of the results of the study with help of spastically analysis of the data .There are various types of experimental designs. The nature of the problem determines which type of design is most appropriate and applicable and how the design should be used to meet the experiment. The experimental design used here is two groups purposively design.

\section{SAMPLE FOR THE STUDY}

In view of some staticians population is also known as universe. The representative proportion of the population is called sample. In order to select sample from a given population, it is also necessary to have a complete, accurate and up-to-date list of all the units in the population. Such a list known as a sampling frame. After defining a population and listing all the units, a researcher selects a sample of units from the sampling frame. The process of such a selection is called sampling.

Sampling is a process by which a relatively small number of individuals on measures of individuals, objects or events is selected and analyzed in order to find out something about the entire population from it was selected. For the method of sampling, there are two categories probability sampling and non-probability sampling. In the absence of any idea of probability the method of sampling is known as non-probability. Randomization is a method of sampling in which each individual of the population has equal chance or probability of selection for constituting a sample.

Total 60 students were assigned 30 students in control group and 30 in experimental group. Groups were initially taken for the study.

TABLE -2

SAMPLE FOR THE STUDY 
Towards Excellence: An Indexed, Refereed \& Peer Reviewed Journal of Higher Education / Dr.

Dhaval Patel / Page 244-253

\begin{tabular}{|l|l|l|l|l|}
\hline \multirow{2}{*}{$\begin{array}{l}\text { Name of The } \\
\text { School }\end{array}$} & \multicolumn{2}{|l|}{$\begin{array}{l}\text { Experimental } \\
\text { Group }\end{array}$} & \multicolumn{2}{l|}{ Control Group } \\
\cline { 2 - 5 } & Girls & Boys & Girls & Boys \\
\hline $\begin{array}{l}\text { Gyandeep Higher } \\
\text { Secondary School }\end{array}$ & 15 & 15 & 15 & 15 \\
\hline & 30 & & 30 & \\
\hline
\end{tabular}

\section{SELECTION OF CONTENT}

The topics for the experimental treatment were selected from the Biology textbook prescribed for 11th Standard (Gujarat state board) for the academic year 2014-2015. Before the selection of the topics, the curriculum and text-book prescribed for Eleventh standard were analyzed for the content and categories such as facts, concepts, principles and generalization. In addition to this, experts and teachers were also consulted to discuss about the programme and get their opinions more about the students understanding levels, suitability of the topics taught in the control group also during the experimental period.

Biology textbook of Eleventh Standard Semester-II 'Anatomy of Flowering Plants' contained units in Biology. The units selected and their major concepts are listed below:

Subject: Biology

Chapter Name: Anatomy of flowering plants

\section{DATA COLLECTION}

Data collection is essentially an important part of the research process. During this process inference, hypothesis or generalization tentively held may be identified by as valid, verified as correct, or rejected as untenable. The data in the present study is in the form of scholastic achievement scores of students in Biology subject.

In educational research, usually two types of data are recognized. They are quantitative and qualitative data. Quantitative data are got by applying various scales of measurement. The quantitative data are either parametric or non-parametric. Parametric data are obtained by 
applying nominal or ordinal scales or measurement. These data are either counted or ranked. Qualitative data are verbal or other symbolic materials. In the present study the researchers has taken scholastic the methodology. After teaching them, with different methodologies i.e. experimental group with Inquiry Training Method and controlled group with Lecture method, a post-test is administered. These scores of post-test are the data for the researcher.

\section{ANALYSIS AND INTERPRETATION OF DATA}

"The analysis and interpretation of the data represent the application of deductive and inductive logic of research process. Interpretation calls for a critical examination of the result of one's analysis in the light of all the limitations of this data gathering and his subjective awareness."

Ho1: There will be no significant difference between Mean scores of achievement of students studying through Inquiry training model and traditional method in Biology of Standard XI.

Table-3

Analysis of Post Test of all the students of controlled Group and Experimental Group

\begin{tabular}{|c|c|c|c|c|c|}
\hline $\begin{array}{c}\text { Types of } \\
\text { Group }\end{array}$ & $\begin{array}{l}\text { No. } \\
\text { (N) }\end{array}$ & $\begin{array}{c}\text { Mean } \\
(\mathbf{X})\end{array}$ & $\begin{array}{l}\text { Standard } \\
\text { Deviation } \\
\text { (SD) }\end{array}$ & t-value & $\begin{array}{c}\text { Level } \\
\text { of significance }\end{array}$ \\
\hline $\begin{array}{l}\text { Controlled } \\
\text { Group } \\
\text { Experimental } \\
\text { Group }\end{array}$ & 30 & 15.9 & $\begin{array}{r}4.65 \\
3.78\end{array}$ & 2.59 & Significant \\
\hline
\end{tabular}

From table 3 it is evident that there are 30 students in controlled group and experimental group. Mean scores of the post test of the students of controlled group and experimental group is respectively 15.9 and 18.73 and SD is 4.65 and 3.78 and $t_{\text {cal }}=2.59$ is more than at $\mathrm{t}_{0.01}$ level=2.58. which indicates that $\mathrm{t}$-value is significant at 0.01 level of 
significance. There will be no significant difference between the achievement of students studying through Inquiry training model and traditional method is rejected at 0.01 level of significance. It means there is significant difference between the traditional method and Inquiry training method. The mean score of experimental group is higher than the control group. It means that student achieve more by Inquiry training method.

Ho2: There will be no significant difference between the mean scores of the achievement of boys of Experimental group and control group of standard XI in Biology.

\section{Table-4}

Analysis of Post Test of all the Boys of controlled Group and Experimental Group

\begin{tabular}{|l|c|c|c|c|c|}
\hline \multicolumn{1}{|c|}{$\begin{array}{c}\text { Types of } \\
\text { Group }\end{array}$} & $\begin{array}{c}\text { No. } \\
(\mathbf{N})\end{array}$ & $\begin{array}{c}\text { Mean } \\
(\mathbf{X})\end{array}$ & $\begin{array}{c}\text { Standard } \\
\text { Deviation } \\
\text { (SD) }\end{array}$ & t-value & $\begin{array}{c}\text { Level of } \\
\text { significance }\end{array}$ \\
$\begin{array}{l}\text { Controlled } \\
\text { Group }\end{array}$ & 15 & 12.2 & 3.36 & \multirow{2}{*}{$\mathbf{5 . 4 5}$} & Significant \\
\cline { 1 - 3 } $\begin{array}{l}\text { Experimental } \\
\text { Group }\end{array}$ & 15 & 17.6 & 4.25 & & \\
\hline
\end{tabular}

From table 4 it is evident that there are 30 Boys in controlled group and experimental group. Mean scores of the post test of the students of controlled group and experimental group is respectively 12.2 and 17.6 and $\mathrm{SD}$ is 3.36 and 4.25 and $\mathrm{t}_{\mathrm{cal}}=5.45$ is more than at $\mathrm{t}_{0.01}$ level=2.58. which indicates that $\mathrm{t}$-value is significant at 0.01 level of significance. Here the hypothesis that there will be no significant difference between the mean scores of the achievement of boys of Experimental group and control group of standard XI in Biology is rejected at 0.01 level of significance .It means that there is significant difference between the achievement of post-test of control group and experimental group. The mean score of experimental group is higher than the control group. It means that Boys achieve more by Inquiry training method. 
Towards Excellence: An Indexed, Refereed \& Peer Reviewed Journal of Higher Education / Dr.

Dhaval Patel / Page 244-253

Ho3: There will be no significant difference between the mean scores of the achievement of girls of Experimental group and control group of standard XI in Biology.

Table-5

Analysis of Post Test of all the Girls of controlled Group and

Experimental Group

\begin{tabular}{|c|c|c|c|c|c|}
\hline $\begin{array}{l}\text { Types of } \\
\text { Group }\end{array}$ & $\begin{array}{l}\text { No. } \\
(\mathbf{N})\end{array}$ & $\begin{array}{c}\text { Mean } \\
(\mathbf{X})\end{array}$ & $\begin{array}{l}\text { Standard } \\
\text { Deviation } \\
\text { (SD) }\end{array}$ & t-value & $\begin{array}{c}\text { Level of } \\
\text { significance }\end{array}$ \\
\hline $\begin{array}{l}\text { Controlled } \\
\text { Group }\end{array}$ & 15 & 19.6 & 2.02 & \multirow{2}{*}{4.41} & \multirow[b]{2}{*}{ Significant } \\
\hline $\begin{array}{l}\text { Experimental } \\
\text { Group }\end{array}$ & 15 & 21.6 & 1.54 & & \\
\hline
\end{tabular}

From table 5 it is evident that there are 30 Girls in controlled group and experimental group. Mean scores of the post test of the Girls of controlled group and experimental group is respectively 19.6 and 21.6 and $\mathrm{SD}$ is 2.02 and 1.54 and $\mathrm{t}_{\mathrm{cal}}=4.41$ is more than table value at $\mathrm{t}_{0.01}$ level $=2.58$. which indicates that $\mathrm{t}$-value is significant at 0.01 level of significance. Here the Hypothesis there will be no significant difference between the mean scores of the achievement of girls of Experimental group and control group of standard XI in Biology is rejected at 0.01 Level of significance. It means there is significant difference between the traditional method and Inquiry training method. The mean score of experimental group is higher than the control group. It means that girls of Experimental group achieve more by Inquiry training method.

Ho4: There will be no significant difference between the mean scores of the achievement of boys and girls of Experimental group of standard XI in Biology. 
Table-6

Analysis of Post Test of Girls and Boys of Experimental Group

\begin{tabular}{|c|c|c|c|c|c|}
\hline $\begin{array}{c}\text { Types of } \\
\text { Group }\end{array}$ & $\begin{array}{c}\text { No. } \\
(\mathrm{N})\end{array}$ & $\begin{array}{c}\text { Mean } \\
(\mathrm{X})\end{array}$ & $\begin{array}{c}\text { Standard } \\
\text { Deviation } \\
\text { (SD) }\end{array}$ & t-value & $\begin{array}{c}\text { Level of } \\
\text { significance }\end{array}$ \\
$\begin{array}{c}\text { Experimental } \\
\text { Group(Boys) }\end{array}$ & 15 & 17.6 & 4.25 & & \\
$\begin{array}{c}\text { Experimental } \\
\text { Group (Girls) }\end{array}$ & 15 & 21.66 & 1.54 & 4.92 & Significant \\
\hline
\end{tabular}

From table 6 it is evident that there are 15 Boys and 15 Girls in experimental group. Mean scores of the post test of the Boys and Girls of Experimental group is respectively 17.6 and 21.6 and $\mathrm{SD}$ is 4.25 and 1.54 and $\mathrm{t}_{\mathrm{cal}}=4.92$ is more than at $\mathrm{t}_{0.01}$ level $=2.58$. which indicates that $\mathrm{t}$-value is significant at 0.01 level of significance Here the Hypothesis that there will be no significant difference between the mean scores of the achievement of boys and girls of experimental group of standard XI in Biology is rejected at 0.01 level of significance. It means there is significant difference between the experimental group of boys and girls. The mean score of girls experimental group is higher than the Boys experimental group. It means that girls of Experimental group achieve more by Inquiry training method as compared to Boys.

\section{CONCLUSION}

The data thus analyzed and interpreted which help the researcher to arrive at findings about research study after analysis and interpretation of the data. The researcher will also give the suggestion for areas in which further research can be carried out.

\section{References :}

A.S Jha (2009), Educational Research New Delhi: APH publication cooperation, Anshari road.

Agarwal J.C.(2004).Principles, Methods and Technology of Teaching (2 ${ }^{\text {nd }}$ Edition)New Delhi : Vikas Publishing House Pvt .Ltd. 
Buch M.B Fourth Survey of Research in Education, 1978-1983, New Delhi (NCERT). Buch M.B Third Survey of Research in Education, 1978-1983, New Delhi (NCERT). Chandra S.S and Sharma R.K. (2002).Research in Education, New Delhi:Amol publication.

J,RichardSuchman (1962):the elementary school training programme in scientific inquiry,report to the us office of education project title vii,project216 urbana university of illinois.

John B.West (1987) Research in Education, Englewood cliffs, New Jersy: Prentice Hall,Inc.

John W. Best (1987) Research in Education, prentice Hall Inc., cliffs, New Jersy,(1997)cited by B.N. Pandey

Joyce, Bruce and Weil,Marsha (1985) :Models of TeachingPrintice Hall India Private Limited New Delhi |

Joyce, Bruce and Weil,Marsha (1985) :Models of TeachingPrintice Hall India Private Limited New Delhi-Fifth Edition-1996

\section{Dr.Dhaval R.Patel \\ Vision College of Education}

Ahmedabad-09. 